\title{
KEADILAN SOSIO-EKONOMI (Kajian atas Distribusi Pendapatan dan Kekayaan yang Merata dalam Perspektif Islâm)
}

\author{
Zainal Abidin \\ (Calon Dosen pada Jurusan Syari'ah STAIN Pamekasan dan Alumni S2 Program \\ Studi Ekonomi Islam IAIN Sunan Ampel Surabaya)
}

\begin{abstract}
Abstrak:
Keadilan merupakan salah satu tujuan utama pembangunan di bidang sosio-ekonomi. Hal ini merupakan salah satu filsafat moral Islâm. Namun ternyata hal itu sangat sulit untuk diaplikasikan. Secara teoritis ternyata memang hal itu sangat lengkap, namun dalam tataran praktis sulit diaplikasikan, sehingga sebenarnya yang menjadi benang kusut adalah bagaimana adanya suatu keberanian untuk mengurai benang kusut tersebut berupa aplikasi dari teori yang ada. Kalau dalam tataran teori sudah baik dan didukung dengan aplikasi yang berkualitas, berupa aktualisasi, maka keadilan akan terwujud yaitu keadilan secara merata berupa distribusi pendapatan dan kekayaan secara merata akan dicapai.
\end{abstract}

Kata kunci:

sosio-ekonomi, pendapatan, dan kekayaan.

\section{Pendahuluan}

Pancasila sila kelima berbunyi "keadilan sosial bagi seluruh rakyat Indonesia". Ia dapat dijabarkan ke dalam butir-butir Pancasila, yaitu: Pertama, mengembangkan sikap adil terhadap sesama. Kedua, menjaga keseimbangan antara hak dan kewajiban. Ketiga, suka memberikan pertolongan pada orang lain. Keempat, suka melakukan kegiatan dalam rangka mewujudkan kemajuan yang merata dan keadilan sosial. ${ }^{1}$

\footnotetext{
1 Pancasila dan UUD 1945 (Surabaya: Apollo, tt), 43.
} 
Ketentuan tersebut menjadi dasar dan arah pembangunan terutama di bidang ekonomi sebagaimana yang dirumuskan di dalam UUD 1945, pasal 33 ayat 2 dan 3 yang berbunyi, "cabang-cabang produksi yang penting bagi negara dan menguasai hajat hidup orang banyak dikuasai oleh negara (2), bumi dan air dan kekayaan alam yang terkandung di dalamnya dikuasai oleh negara dan dipergunakan untuk sebesar-besar kemakmuran rakyat (3)".2

Uraian tersebut sangat jelas bahwa orientasi pembangunan negara Indonesia dalam bidang ekonomi adalah demi tercapainya keadilan bagi seluruh rakyat Indonesia, terutama di bidang ekonomi, di mana semua cabang-cabang produksi yang menguasai hajat hidup orang banyak dikuasai oleh negara, sehingga di harapkan semua rakyat dapat memenuhi hajat hidupnya.

Hal tersebut tertangkap sangat jelas dalam ayat ke-4 dari pasal 33 UUD 1945 dalam amandemen keempat dinyatakan bahwa perekonomian nasional diselenggarakan berdasar atas demokrasi ekonomi dengan prinsip kebersamaan, efisiensi berkeadilan, berkelanjutan, berwawasan lingkungan, kemandirian, serta dengan menjaga keseimbangan kemajuan dan kesatuan ekonomi nasional. ${ }^{3}$

Ada beberapa tujuan pensyari'atan Islâm. Tujuan itu terbagi atas tiga kategori,yaitu: Pertama, dlaruriyah, yaitu segala sesuatu yang harus ada untuk tegaknya kehidupan manusia baik diniyah maupun duniawiyah. Hal tersebut terjabarkan ke dalam hifzh al-nafs (memelihara jiwa), hifzh al-dîn (memelihara agama), hifzh al-'aql (memelihara akal), hifzh al-nasl (memelihara keturunan), dan hifzh almâl (memelihara harta). kesemuanya harus diusahakan untuk ditegakkan dan dihindari segala sesuatu yang mencederainya. Kedua, hâjiyah, yaitu segala sesuatu yang dibutuhkan untuk menghindari keterjepitan dalam hidup menuju kelapangan. Ketiga, tahsiniyah, yaitu kebutuhan yang layak dan pantas dan dibenarkan oleh syarî'ah demi kebahagiaan manusia. ${ }^{4}$

Selanjutnya, prinsip-prinsip syarî'ah, terutama di bidang hifzh al-mâl, dapat dijabarkan ke dalam tiga bagian, yaitu: (1) Tahdîf al-

2 Sekretariat Jenderal MPR RI, Undang-Undang Dasar Negara Republik Indonesia Tahun 1945 dalam Satu Naskah (Jakarta: tp., 2006), hlm. 69.

${ }^{3}$ Ibid.

${ }^{4}$ M. Hasbi Ash-Shiddieqy, Falsafah Hukum Islam (Jakarta: Bulan Bintang, 1975), hlm. 190-191. 
afradh (terjaminnya kebutuhan individu), (2) iqâmah al-'adl (tegaknya keadilan), (3) tahqî̀ al-mashâlih al-'âmmah (mengokohkan kemaslahatan umum). ${ }^{5}$ Ini menunjukkan bahwa konsep Islâm menekankan pada keseimbangan antara kebutuhan individu dan kebutuhan sosial. Dengan kata lain, keadilan merupakan tujuan utama pembangunan dalam konsep Islâm.

Walaupun Indonesia tidak mendeklarasikannya sebagai negara agama (teokrasi) negara atheis, namun sangat jelas terlihat dalam UUD 1945, tepatnya pasal pasal 29 ayat 1, yang berbunyi "negara berdasar atas Ketuhanan Yang Maha Esa". Hal itu dijelaskan lebih lanjut pada ayat 2, bahwa "negara menjamin kemerdekaan tiaptiap penduduk untuk memeluk agamanya masing-masing dan untuk beribadat menurut agamanya dan kepercayaanya itu". ${ }^{6}$

Dalam konteks Indonesia konsep Islâm tersebut sangat bisa diterapkan. Hal itu sebagai bentuk perwujudan dari pengamalan keagamaan terutama di bidang ekonomi. Islâm kâffah tentunya menginginkan perjalanan roda perekonomiannya sesuai dengan prinsip-prinsip syarî'ah. Keinginan tersebut tentunya tidak bisa serta merta dapat terwujud dengan sekejap mata. Hal itu memerlukan sebuah perjuangan panjang dan melelahkan. Salah satu caranya adalah pemerintah harus diisi oleh orang-orang yang mempunyai semangat untuk menerapkan ajaran Islâm melalui berbagai cara yang legal dan berkesinambungan. Tanpa adanya ini sangat sulit karena pemimpin sepatutnya harus berorientasi pada mashlahah ' $\hat{a} m m a h$.

Di samping itu rakyat harus mendukung setiap adanya usaha untuk menerapkan konsep yang berasal dari Tuhan, karena memang konsep yang lain sampai saat ini dirasa belum mampu membawa perbaikan pada kehidupan ini, terutama di bidang ekonomi. Hal itu bisa dibenarkan karena Indonesia adalah negara demokrasi, artinya yang berhak mengatur, pada tataran substansinya adalah rakyat. Karenanya, benar apa yang dikatakan Chapra bahwa faktor politik merupkan salah satu strategi bagi suatu negara untuk mengatur

5Sjechul Hadi Permono, Pemerintah RI sebagai Pengelola Zakat (Jakarta: Pustaka Firdaus, 1992), hlm. 119-120.

6Sekretariat Jenderal MPR RI, Undang-Undang Dasar, hlm. 67-68. 
pembangunan negaranya, termasuk ekonomi, demi tercapainya pembangunan yang berkeadilan. ${ }^{7}$

Oleh karena itu pembangunan terutama di Indonesia bisa diusahakan untuk sesuai dengan tuntunan agama Islâm yang menitik beratkan pada konsep keadilan terutama dalam bidang sosioekonomi, yang salah satunya distribusi pendapatan dan kekayaan yang merata.

\section{Konsep Keadilan sosio-ekonomi}

Keadilan (al-'adalah) merupakan fondasi pertama bagi suatu negara yang dibangun berdasarkan ajaran Islâm. Negara dan masyarakat harus ditegakkan di atas keadilan dalam arti seluasluasnya, tidak hanya keadilan hukum, melainkan juga keadilan keadilan sosio-ekonomi. Dengan demikian negara harus memberantas setiap fenomena dan bentuk eksploitasi yang muncul di tengah masyarakat, menjamin persamaan setiap orang di muka hukum. Persamaan kesempatan yang menjadi semboyan kebanggaan kapitalisme dan liberalisme tidak dibenarkan oleh Islâm karena akan melahirkan ketidaksamaan dan ketimpangan di antara kelas-kelas di tengah-tengah masyarakat, hal disebabkan oleh titik berangkat dari masing-masing kelas tidak sama. Berdasarkan persamaan kesempatan ini, yang kaya makin kaya, sedang yang miskin akan tetap dalam kemiskinannya. ${ }^{8}$

Prinsip persamaan akhir, sama rata, dan sama rasa yang menjadi prinsip dasar pembangunan negara dan masyarakat komunis, juga tidak dibenarkan oleh Islâm, karena juga melahirkan ketidakadilan, dalam arti mereka yang cerdas dan bodoh, yang rajin dan malas, yang dinamis dan statis, harus menikmati hasil yang sama, sehingga prinsip ini akan mengendorkan bahkan membunuh kreativitas manusia. Islâm memang mentoleransi perbedaan tingkat kekayaan yang dimiliki masing-masing anggota masyarakat dalam suatu negara, akan tetapi perbedaan tersebut tidak boleh terlalu menyolok, sehingga menimbulkan perbedaan kelas yang tajam serta kebencian sosial antar kelas. Islâm menentukan lembaga pemerataan

\footnotetext{
${ }^{7}$ Lihat M. Umer Chapra, Islam dan Pembangunan Ekonomi, ter,. Ikhwan Abidin (Jakarta: Gema Insani Press, 2000), hlm. 151.

8 Permono, Pemerintah RI, hlm. 34-35.
} 
ekonomi agar tidak terjadi kesenjangan yang menyolok antara si kaya dengan si miskin, misalnya zakat, khums, dan sebagainya. Jika zakat belum mampu melakukan proses pemerataan ke arah keadilan sosioekonomi, maka pemerintah dengan kedaulatannya dapat mengambil sebagian harta dari kelompok kaya untuk diberikan kepada mereka yang membutuhkannya, sampai benar-benar terjadi keadilan. ${ }^{9}$

Banyak sekali ayat-ayat al-Qur'ân ${ }^{10}$ yang menegaskan perlunya keadilan bagi semua bidang kehidupan dan umat Muslim seharusnya menegakkan keadilan. Negara merupakan lembaga paling mampu memberikan keadilan kepada rakyat. Oleh karenanya, pemerintah Islâm terikat dan wajib berlaku adil. ${ }^{11}$

Islâm tidak mempermasalahkan keadaan akhir dari seseorang, apakah ia termasuk dalam golongan fakir miskin maupun kaya. Islâm hanya akan mempersoalkan bagaimana seseorang bersikap dan mempergunakan hartanya. Sehingga nanti yang akan ditanyakan Tuhan kepada hambanya adalah dari mana harta itu dan bagaimana cara menafkahkannya? Bukan ditanya berapa jumlahnya. Kaya dan miskin merupakan sunnâtullah yang tidak bisa dihilangkan. Manfaat dari kondisi tersebut sangat dirasakan yaitu tetap berputarnya roda dunia kehidupan ini. Apa yang akan terjadi jika kondisi manusia semuanya kaya, atau semuaanya miskin. Itulah sebenarnya letak keadilan dari Tuhan.

Adil ${ }^{12}$ merupakan salah satu sifat yang harus dimiliki oleh manusia dalam rangka menegakkan kebenaran kepada siapapun tanpa kecuali, walaupun akan merugikan diri sendiri baik secara individu maupun kelompok. Di sini, penting untuk membedakan konsepsi keadilan antara rasa kesamaan yang merupakan salah satu aspek dari konsep adil dan juga merupakan salah satu unsur dari ideal sosial yang lebih luas, karena kadangkala ketidaksamaan oleh

9Ibid., hlm. 35-36.

${ }^{10}$ Lihat al-Qur'ân surat al-Nahl (16): 90 dan surat al-Mâ`idah (5): 8.

11Permono, Pemerintah RI, hlm. 37.

12Secara etimologis, al-'adl berarti tidak berat sebelah, tidak memihak. Sedangkan dalam terminologinya adalah mempersamakan sesuatu dengan yang lain dari segi ukuran, sehingga sesuatu itu tidak menjadi berat sebelah dan tidak berbeda satu dengan yang lainnya. Atau juga diberikan arti meletakkan sesuatu pada tempatnya. Lihat Nasrun Harun et. al., Ensiklepodi Hukum Islam, Vol. I (Jakarta: Ichtiar Baru Van Hoeve, 1996), hlm. 25. 
seseorang dianggap adil bagi orang lain. ${ }^{13}$ Oleh sebab itu maka penulis akan memberikan penekanan pada arti yang lazim yang hakikatnya adalah peniadaan pembeda-pembeda yang arbiter, suatu keseimbangan yang tepat antara tuntutan yang saling bersaing, atau tidak menzhalimi atau dizhalimi. ${ }^{14}$

Sifat Tuhan Yang Maha Adil sekaligus mencakup pengertian Maha Bijaksana dan Maha Benar. Segala sesuatu yang diatur Tuhan terjadi karena kejadian itulah yang paling benar, paling bijaksana dan karenanya paling adil. ${ }^{15}$ Bukan hanya itu, Tuhan juga sangat jelas dalam memerintahkan hamba-Nya untuk senantiasa berbuat adil bagi sesamanya.

Ironisnya, di mayoritas negara Muslim, upah materiil menjadi semakin tidak adil sehingga mayoritas orang tidak dapat memperoleh upah yang cukup bagi kerja keras, kreativitas, dan kontribusinya pada output. Karena itu menjadi apatis. Sementara inisiatif, dorongan kerja, dan efisiensinya sangat dirugikan. Setidaknya ada dua faktor yang menyebabkan keadaan ini terjadi, yaitu: Pertama, bias dan kurangnya realisme dalam kebijakan-kebijakan resmi. Kedua, konsentrasi kekayaan dan juga kekuasaan di tangan segelintir orang, baik di pedesaan dan perkotaan. ${ }^{16}$

Adanya bias dan kurangnya realisme kebijakan-kebijakn resmi telah menyebabkan distorsi harga-harga pokok yang secara tidak disadari mengakibatkan penurunan pendapatan petani-penyewa, pengusaha kecil dan mikro, dan para buruh. Demikian juga akan mengurangi permintaan mereka terhadap kebutuhann dan menciptakan misalokasi sumber-sumber daya untuk memenuhi kebutuhan pokok. Sementara konsentarasi kekayaan dan kekuasaan juga terjadi, sebagian karena kebijakan-kebijakan resmi dan sebagian lainnya karena sistem ekonomi eksploitatif yang telah berlangsung berabad-abad lamanya, yang membatasi persaingan, menimbulkan

\footnotetext{
${ }^{13}$ Andrew Blower dan Grahame Thompson, Ketidakmerataan Konflik dan Perubahan (Jakarta: UI Press, 1983), hlm. 145.

${ }^{14}$ Adimarwan A. Karim, Ekonomi Mikro Islam (Jakarta: IIIT Indonesia,2002), 179.

${ }^{15}$ M. Amin Aziz, Sekitar Kemiskinan dan Keadilan: Dari Cendekiawam Kita tentang Islam (Jakarta: UI Press, 1987), hlm. 65.

${ }_{16}$ M. Umer Chapra, Islam dan Tantangan Ekonomi (Jakarta: Gema Insani Press, 2000), hlm. 252.
} 
kolusi merajalela, dan telah menciptakan suatu iklim yang kondusif yang melahirkan petaka bagi masyarakat yang lemah. ${ }^{17}$

Dari uraian di atas dapat dipahami adanya faktor-faktor penyebab kondisi tidak adil. Oleh karena itu penting diusahakan langkah-langkah untuk menghilangkan faktor tersebut. Ada beberapa langkah yang mungkin dapat diusahakan, antara lain, yaitu:

1. Reformasi perburuhan

Nilai-nilai Islâm menghendaki para majikan memperlakukan buruhnya seperti anggota keluarga sendiri. Hal ini menuntut agar para karyawan diperlakukan dengan hormat dan kasih sayang serta kesejahteraan mereka harus dijamin. Idealnya tingkat upah riil dalam masyarakat muslim paling tidak memungkinkan karyawan dapat memenuhi semua kebutuhan pokok dan para anggota keluarganya dengan cara manusiawi. Mereka harus diberi pula pelatihan, jaminan keamanan pekerjaan dan kalau bisa saham keuntungan dalam kerangka kerja jangka panjang serta hubungan yang harmonis. ${ }^{18}$

Preskripsi upah minimal barang kali tidak akan menyelesaikan masalah, sulit rasanya memberlakukan dan kalau pun diberlakukan akan memiliki dampak buruk. Misalnya, hal itu akan menimbulkan perbedaan dalam upah yang dilaporkan kepada pihak yang berwenang, sehingga bisa mereduksi kewajiban pajak yang dibayarkan tanpa memberikan manfaat apa pun terhadap buruh. Pada akhirnya akan memperparah tingkat pengangguran yang ada. Oleh karena itu perlu diperkenalkan suatu kebijakan yang akan menghapus eksploitasi, dengan meningkatkan produktivitas pekerja dan ekspansi peluang wirausaha. Kebijakan demikian lebih jauh harus diperkuat dengan memperkuat rencana kepemilikan saham dan bagi hasil kepada karyawan seluas mungkin. Ketika menerapkan skema bagi hasil perlu dijamin bahwa kebijakan ini tidak menimbuklkan eksploitasi. Hal ini bisa terjadi jika gaji pokok yang tidak kena resiko, tidak memenuhi kebutuhan pokok para pekerja.

Di samping itu penerapan kepemilikan saham ini dan juga bagi-hasil akan mengurangi konsentrasi kekayaan dan kekuasaan. Hal itu memungkinkan para pekerja untuk menjadi pemilik saham

17 Ibid., hlm. 252-253.

18 Ibid., hlm. 253-254. Lihat juga M. Umer Chapra, Islam dan Pembangunan Ekonomi, terj., Ikhwan Abidin (Jakarta: Gema Insani Press, 2000), hlm. 88-89. 
sehingga meningkatkan kepemilikan mereka pada keberhasilan perusahaan. Akhirnya akan mengurangi konflik industrial dan meningkatkan kejujuran serta efisiensi pekerja. Fenomena ini juga meningkatkan tabungan dan mengurangi penimbunan emas yang tidak produktif serta dapat meningkatkan status sosial mereka dalam perusahaan dan masyarakat. Hal ini sudah lama dipraktikkan di negara-negara kapitalis seperti Prancis, Inggris, sehingga tidak ada alasan untuk tidak mendapatkan dukungan di negara-negara muslim. ${ }^{19}$

Sejarah mencatat bahwa Rasûlullâh saw. sebagai pemimpin negara, pernah didatangi oleh seseorang yang tidak memiliki sarana yang dapat digunakan untuk bekerja. Beliau lalu memanggilnya sambil memegang kapak dan sepotong kayu, kemudian menyuruhnya bekerja dengan alat itu. Dari kisah ini negara mempunya kewajiban untuk menyediaakn lapangan pekerjaan yang cukup bagi para penduduknya, ${ }^{20}$ atau minimal memberikan nuansa yang merangsang timbulnya dunia kerja, seperti menjamin adanya kepastian hukum, keamanan, dan lain sebagainya.

\section{Pendidikan dan latihan}

Kontribusi tidak ternilai yang dapat disumbangkan oleh pendidikan dan pelatihan yang tepat bagi perbaikan kualitan SDM, keadilan sosio-ekonomi yang lebih besar dan pertumbuhan yang lebih cepat, kini diakui secara universal. Pendidikan membuka persamaan sosial dan peluang ekonomi, dan telah dipandang sebagai "roda keseimbangan mesin sosial". Sayangnya pemerintah negaranegara Muslim mengabaikan sektor yang amat penting ini ke dalam sumber dayanya. Bahkan melek huruf yang merupakan langkah awal dalam alur pendidikan, belum bersifat universal di kebanyakan negara Muslim. Yang sangat aneh adalah pengabaian pendidikan wanita, yang bergantung pada karakter, kesehatan, dan kemampuan generasi sekarang dan yang akan datang. Pengabaian seperti ini tidak dapat diteruskan karena akan menghancurkan jaringan kesatuan masyarakat Muslim.

\footnotetext{
19 Ibid., hlm. 254-256.

${ }^{20}$ Abd al-'Aziz al-Badri, Hidup Sejahtera di bawah Naungan Islam, (Jakarta: Gema Insani Press, 1995), hlm. 28.
} 
Penekanan utama pendidikan harus pada pencetakan manusia yang produktif dan baik. Inilah yang akan membantu memobilisasi semangat dan bakat yang masih terpendam di negara-negara Muslim. Setiap mahasiswa Muslim harus dididik menjadi seorang Muslim yang baik dan diberi motivasi kuat untuk menciptakaan kualitaskualitas ini pada dirinya. Namun hal ini tidak memadai, masih perlu mengajarinya dengan keterampilan-ketrerampilan yang diperlukan dan teknik-teknik pemasaran, manajemen, dan produksi yang paling efisien.

Sistem pendidikan sekuler di negara-negara muslim tidak saja gagal mencetak mahasisiwa yang lebih baik, yang diperkaya dengan karakteristik muslim yang baik dan sadar akan tanggung jawabnya kepada masyarakat tetapi juga gagal mencetak mereka menjadi lebih produktif dengan mengajariny keterampilan yang diperlukan. Sebagai akibatnya adalah terjadinya peningkatan tajam jumlah sarjana menganggur di wilayah-wilayah perkotaan, meskipun terdapat kelangkaan manusia yang terlatih di sektor-sektor tertentu dalam ekonomi. Di samping itu adanya kesenjangan antara si kaya dan si miskin dalam mengakses pendidikan.

Dengan demikian perlu suatu perubahan substansial dalam kurikulum dengan memasukkan nilai-nilai Islâm dan keterampilanketerampilan teknik yang dibutuhkan. Di samping itu juga perlu mendirikan suatu jaringan kelembagaan yang tersebar luas sehingga keluarga miskin bisa mendapatkan akses pendidikan dan pelatihan yang sangat dibutuhkan. Cara ini sangat penting untuk menghapuskan sumber-sumber ketidakadilan dan kemiskinan serta menyediakan bagi siapa saja suatu peluang untuk maju ke depan atas dasar kemampuannya. ${ }^{21}$

\section{Akses pada keuangan}

Kurangnya akses bagi orang miskin pada keuangan memang merupakan faktor yang sangat krusial, yang menggagalkan usaha memperluas kepemilikan bisnis dan industri, sehingga menghambat tujuan merealisasikan sasaran-sasaran egalitarian Islâm. Jika tindakan-tindakan efektif tidak diambil untuk menghapuskan kelemahan ini, maka sebuah sistem pendidikan yang merata dan

${ }^{21}$ Capra, Islam dan Tantangan Ekonomi, hlm. 259-261. 
lebih baik tidak hanya akan meningkatkan efisiensi dan pendapatan, tetapi secara substansial tidak efektif di dalam mengurangi ketidakmerataan kekayaan. Berbicara tentang masyarakat Islâm yang egalitarian hanya akan mebuang-buang waktu saja. Untunglah Islâm mempunyai keunggulan sendiri di atas kapitalisme dan sosialisme dalam sistem finansial yang dibangun di atas sistem nilainya dan yang memberikan kekuatan pendorong untuk mencapai tujuan keadilan sosio-ekonomi. ${ }^{22}$

\section{Distribusi Pendapatan dan Kekayan yang Merata: Perspektif Islâm}

Islâm telah membolehkan kepemilikan pribadi, namun Islâm juga menentukan bagaimana cara memilikinya. Islâm juga telah memberikan izin kepada individu untuk mengelola harta yang telah menjadi hak miliknya, namun Islâm telah menentukan bagaimana cara mengelolanya. Islâm menyadari ada perbedaan akal serta fisik manusia, sehingga Islâm selalu membantu individu yang lemah serta mencukupi kebutuhan yang membutuhkannya. Islâm mewajibkan kepada manusia di mana dalam harta orang-orang kaya terdapat hak bagi fakir miskin, baik dia memintanya atau tidak. Islâm telah menjadikan harta yang senantiasa dibutuhkan oleh jama'ah sebagai hak milik umum bagi seluruh kaum Muslim, di mana tidak seorang pun boleh memilikinya atau mempertahankannya untuk kepentingan pribadi, ataupu $\mathrm{n}$ yang lain. Seperti halnya Islâm telah menjadikan negara sebagai penanggung jawab atas terpenuhinya kekayaan untuk rakyat, baik berupa harta maupun jasa. Islâm juga membolehkan negara untuk memiliki suatu kepemilikan khusus terhadap kekayaan tersebut. ${ }^{23}$

Atas dasar inilah, maka Islâm menjamin kehidupan tiap individu-rakyat serta menjamin jamâ'ah untuk tetap sebagai sebuah komunitas yang saling berpegang pada ketentuan yang ada. Islâm juga menjamin kemaslahatan individu dan melayani urusan jamâ'ah, serta menjaga eksistensi negara dan kekuatan yang cukup sehingga mampu memikul tangung jawab perekonomian negara. Hanya saja, semuanya bisa terjadi jika masyarakat tetap dalam kondisi di mana

22 Ibid., hlm. 261. Lihat juga M. Umer Chapra, Islam dan Pembangunan Ekonomi, ter, Ikhwan Abidin (Jakarta: Gema Insani Press, 2000), hlm. 96-97.

23 Taqiyuddin al-Nabhani, Membangun Sistem Ekonomi Alternatif; Persfektif Islam, terj. M. Maghfur Wahid (Surabaya: Risalah Gusti, 1990), hlm. 271. 
kekayaan yang ada bisa mencukupi kebutuhan rakyat, secara pribadi dan rakyat-secara keseluruhan- menerapkan semua hukum syara' ${ }^{24}$ Akan tetapi apabila masyarakat berdiri di atas kesenjangan yang lebar antar individu dalam memenuhi kebutuhannya, sebagaimana kondisi yang terjadi di dunia Islâm saat ini, maka harus diwujudkan adanya keseimbangan antar individu rakyat dalam mengupayakan distribusi baru, yang bisa merata dalam memenuhi kebutuhan-kebutuhannya. ${ }^{25}$

Demikian halnya kalau terjadi penyimpangan dalam benak manusia dalam menerapkan hukum syara', karena adanya pemahaman yang keliru atau terjadinya kebobrokan. Kondisi inilah yang menyebabkan terjadinya praktik monopoli dan individualis, sekaligus rusaknya pengelolaan hak milik pribadi, sehingga secara otomatis akan terjadi kerusakan dalam distribusi kekayaan kepada individu. Sehingga keseimbangan dalam masyarakat harus dijagakalau sudah ada- atau mungkin di wujudkan -kalau belum ada-.

Prinsip itu sesuai dengan prinsip Islâm, karena Islâm telah mewajibkan sirkulasi kekayaan terjadi pada semua anggota masyarakat dan mencegah terjadinya sirkulasi kekayaan hanya kepada segelintir orang. Allâh berfirman, "...Supaya harta itu jangan hanya beredar di antara orang-orang kaya saja di antara kamu.26 Maksud dari penggalan ayat tersebut adalah supaya harta tersebut tidak berputar di antara orang-orang kaya saja. Kata dulah dalam bahasa Arab adalah sebutan untuk benda yang diputar oleh suatu kaum. Kata tersebut juga berarti nama untuk harta yang terus diputar. ${ }^{27}$

Apabila masyarakat mengalami kesenjangan yang lebar antar individu dalam memenuhi kebutuhannya, lalu ingin dibangun kembali masyarakat, atau terjadi kesenjangan karena mengabaikan hukum-hukum, maka negara harus memecahkannya dengan cara memberikan harta negara yang menjadi miliknya kepada orang yang memiliki keterbatasan dalam memenuhi kebutuhannya, atau yang dikenal dengan istilah subsidi. Oleh karena itu, negara bisa mencukupinya, sehingga terjadi keseimbangan di dalam memenuhi kebutuhannya. ${ }^{28}$

\footnotetext{
24 Ibid.

25 Ibid.

${ }^{26}$ Al-Qur'ân surat al-ㅍasyr: 7.

${ }^{27}$ al-Nabhani, Membangun Sistem Ekonomi, hlm. 274.

${ }^{28}$ Ibid., hlm. 272.
} 
Dengan demikian pada saat negara melihat adanya ancaman terhadap keseimbangan ekomomi di dalam masyarakat, maka negara harus menyelesaikan ancaman tersebut, dengan cara mensuplai orang yang tak sanggup memenuhi kebutuhannya, yang salah satu sumbernya dengan harta dari bayt al-mâl. ${ }^{29}$ Oleh karena itu khalîfah harus menciptakan keseimbangan ekonomi. Khalîfah harus menciptakan keseimbangan ekonomi tersebut dengan menyuplai rakyat yang fakir dengan harta yang diambilkan dari bayt al-mâl yang merupakan milik seluruh kaum muslimin. Sehingga dengan suplai tersebut bisa diwujudkan keseimbangan ekonomi. ${ }^{30}$

Dalam pandangan lain, Chapra memberikan suatu penjelasan bahwa dalam menyelesaikan pendistribusian ini perlu dilengkapi dengan beberapa instrumen. Sistem pasar memang diperlukan, tetapi hal itu tidak akan mencukupi, sehingga perlu dilengkapi dengan peran aktif pemerintah dan yang paling penting adalah reformasi moral individual yang beroperasi di pasar. ${ }^{31}$

\section{Mengurangi konsentrasi kekayaan}

Seperti telah dijabarkan bahwa Allâh menganjurkan untuk tidak memusatkan kekayan hanya di kalangan orang kaya saja, maka perlu diusahakan bagaimana cara mengurangi konsentrasi kekayaan tersebut, sehingga ada pemerataan kekayaan yang dimulai dengan pemerataan pendapatan.

Tulisan ini mencoba menawarkan langkah-langkah demi tercapainya kondisi tersebut, yaitu:

1. Reformasi ukuran pemilikan tanah.

Sekiranya tanah itu telah dimiliki lewat cara-cara yang fair dan ditanami baik oleh pemiliknya atau disewakan kepada petani penggarap berdasarkan persyaratan yang adil, dan sistem pewarisan Islâm sepenuhnya diterapkan, maka kepemilkan tanah tidak akan terkonsentrasi pada segelintir keluarga saja. Tetapi, karena tanah telah dimiliki selama berabad-abad melalui cara-cara yang tidak jujur, sementara sistem warisan Islâm telah ditinggalkan, maka kepemilikan

\footnotetext{
29 Ibid.,

30Ibid., hlm. 274.

${ }^{31}$ M. Umer Chapra, Masa Depan Ilmu Ekonomi; Sebuah Tinjauan Islam, terj. Ikhwan Abidin (Jakarta: Gema Insani Press, 2001), hlm. 261.
} 
tanah tidak terdistribusikan secara merata sehingga memaksakan mayoritas penduduk pedesaan pada kehidupan perbudakan, kemiskinan dan kesulitan. Mengingat keadaan yang sangat tidak adil ini, maka perlu membatasi ukuran maksimal kepemilikan tanah dan mendistribusikan sisanya secara merata di antara petani yang tidak memiliki tanah. ${ }^{32}$

2. Zakat

Preskripsi zakat merupakan tanda terang dan tidak mengandung kekaburan tentang keinginan Tuhan untuk menjamin tidak seorang pun menderita karena kekurangan sarana untuk memenuhi kebutuhan pokok. ${ }^{33}$ Di samping zakat sebagai amal ibadah yang berdimensi ketuhanan, juga akan mendatangkan manfaat yang luar biasa dalam dimensi kemanusiaan. Zakat merupakan suatu cara yang efektif di dalam pemerataan kekayaan, walaupun memerlukan proses yang panjang dan terus menerus.

\section{Kewarisan}

Islâm telah menegakkan sebuah sistem kewarisan unik yang direkayasa untuk mampu menciptakan distribusi kekayaan yang lebih merata. Hukum waris telah dilakukan oleh syarî'ah berdasarkan tujuan sosio-ekonominya. Tak seorang pun dapat menjauhkan pewaris syar' $\hat{\imath}$, kecuali bila ia murtad atau bersalah membunuh yang mewarisi. Di samping itu, tak seorang pun dapat menerima wasiat lebih dari sepertiga kekayaan. Sepertiga kekayaan itu harus diperuntukkan bagi tujuan-tujuan kebajikan untuk orang-orang yang tidak memilki saham warisan kecuali ahli waris lainnya menyetujuinya. ${ }^{34}$ Efek positif zakat pada distribusi pendapatan dan kekayaan akan didorong lebih jauh oleh sistem pewarisan, demikian juga oleh sedakah, hibah, wakaf, dan hadiah. ${ }^{35}$

Hal itu bisa dibuktikan dengan alur berpikir dan berusaha mencari jawaban dari sebuah pertanyaan bagaimana kondisi pewarisan harta jika tidak ada aturan hukum waris. Sangat bisa

32Ibid., hlm. 264. Lihat juga M. Umer Chapra, Islam dan Pembangunan Ekonomi, hlm. 99-100.

${ }^{33}$ Chapra, Masa Depan, hlm. 270.

34 Ibid., hlm. 275.

${ }_{35}$ M. Abdul Mannan, Teori dan Praktek Ekonomi Islam, terj. M. Nastangin (Yogyakarta: Dana Bhakti Prima Yasa, 1997), hlm. 113-114. 
diprediksi bahwa akan ada konsentrasi yang sangat tidak seimbang dalam konsentrasi kekayaan, karena orang tua akan mewariskan hartanya hanya pada ahli waris tertentu dari sekian ahli warisnya. Mungkin hanya diberikan pada anak perempuannya yang tercantik, atau bisa saja hanya diberikan pada anak lelakinya yang paling tampan. Kalau hal itu terjadi betapa tidak adilnya distribusi kekayaan tersebut. Jadi sangat jelas bahwa pewarisan Islâm merupakan salah satu cara mengurangi konsentrasi kekayaan, minimal distribusi dalam keluarga tersebut.

\section{Penutup}

Pembangunan di bidang ekonomi adalah untuk menciptakan keadilan sosio-ekonomi berupa meratanya distribusi pendapatan dan kekayaan. Sedangkan tujuan dari konsep itu sudah jelas dianggap sebagai bagian tak terpisahkan dari filsafat moral Islâm dan didasarkan pada komitmennya pada persaudarannya manusia, yang sangat ditekankan oleh al-Qur'ân dan al-Hadîts. Kedua tujuan ini terintegrasi sangat kuat di dalam ajaran-ajaran Islâm sehingga realisasinya menjadi komitmen spiritual bagi masyarakat Muslim. ${ }^{36}$ Demikian juga bagi masyarakat Indonesia sebagai mayoritas muslim yang mewarnai negara ini, sehingga sangat sulit rasanya membedakan istilah Indonesia dengan istilah Islâm.

Islâm bukan hanya menyentuh akar ketidakadilan dari sekedar menyembuhkan gejala-gejalanya, tetapi dalam Islâm telah ada sejumlah langkah yang tidak mengizinkan terjadinya distribusi pendapatan yang tidak adil. Lebih dari itu, Islâm juga mempunyai built-in-program untuk mengurangi ketidakadilan yang masih tersisa, melalui serangkaian program yang coba ditawarkan sedemikian hingga, sehingga bisa dilaksanakan pendistribusian pendapatan yang sesuai dengan konsep di atas. ${ }^{37}$ Sehingga jelas antara Indonesia dan Islâm dalam tataran konsep terjadi irisan yang dekat dan sulit untuk dibedakan apalagi dalm hal memperjuangkan keadilan bagi kehidupan manusia.

Sudah sangat jelas dalam tataran konsep, tetapi dalam realitanya mengapa sering terjadi ketidakadilan? Jawaban dari itu

${ }^{36}$ M. Umer Chapra, Al-Qur'an menuju Sistem Moneter yang Adil, terj. Lukman Hakim (Yogyakarta: Dana Bhakti Prisma Yasa, 1997), hlm. 5.

37 Ibid. 
semua mungkin sejauh mana praktik bisa sesuai dengan teori yang diberikan, atau dalam istilah lain sejauh mana konsep itu "berani" diaktualisasikan dalam kehidupan sehari-hari, walaupun tidak harus sama persis, tetapi minimal mendekati, sehingga bisa diharapkan dapat menuju poros rasa keadilan, walupun mustahil (untuk mengatakan sangat sulit) tercapainya rasa keadilan yang sesuai dengan harapan semua pihak. Wallâh a' lam bi al-Shawab.

\section{Daftar Pustaka:}

Aziz, M. Amin. Sekitar Kemiskinan dan Keadilan: Dari Cendekiawam Kita Tentang Islam,Cet. I. Jakarta: UI Press, 1987.

Badri, Abd al- 'Aziz Al-. Hidup Sejahtera di bawah Naungan Islam, Jakarta: Gema Insani Press, 1995.

Blower, Andrew dan Grahame Thompson. Ketidakmerataan Konflik dan Perubahan, Jakarta: UI Press, 1983.

Chapra, M. Umer. Islam dan Pembangunan Ekonomi, terj. Ikhwan Abidin. Jakarta: Gema Insani Press, 2000.

Islam Dan Tantangan Ekonomi. Jakarta: Gema Insani Press, 2000.

. Masa Depan Ilmu Ekonomi Sebuah Tinjauan Islam, ter,. Ikhwan Abidin. Jakarta: Gema Insani Press, 2001.

.Al-Qur'an Menuju Sistem Moneter Yang Adil, terj. Lukman Hakim. Yogyakarta: Dana Bhakti Prisma Yasa, 1997.

Departemen Agama RI. Al-Qur'an dan Terjemahannya. Jakarta: PT. Bumi Restu, 1989.

Harun, Nasrun, et. al. Ensiklepodi Hukum Islam, Vol. I. Jakarta: Ichtiar Baru Van Hoeve, 1996. 
Karim, Adimarwan A. Ekonomi MIkro Islam. Jakarta: IIIT Indonesia, 2002.

Mannan, M. Abdul. Teori Dan Praktek Ekonomi Islam, terj. M. Nastangin. Yogyakarta: Dana Bhakti Prima Yasa, 1997.

Nabhani, Taqiyuddin Al-. Membangun Sistem Ekonomi Alternatif; Perspektif Islam, terj. M. Maghfur Wahid. Surabaya: Risalah Gusti, 1990.

Permono, Sjechul Hadi. Pemerintah RI Sebagai Pengelola Zakat. Jakarta: Pustaka Firdaus, 1992.

Sekretariat Jenderal MPR RI, Undang-Undang Dasar Negara Republik Indonesia Tahun 1945 dalam Satu Naskah, Jakarta: Tanpa Penerbit, 2006.

Ash-Shiddieqy, M. Hasbi. Falsafah Hukum Islam, Jakarta: Bulan Bintang, 1975. 